\title{
Ablation of hepatic malignant tumors with irreversible electroporation: A systematic review and meta-analysis of outcomes
}

\author{
Guo Tian ${ }^{1,2}$, Qiyu Zhao ${ }^{3}$, Fen Chen ${ }^{4}$, Tian'an Jiang ${ }^{3}$, Weilin Wang ${ }^{2,4}$ \\ ${ }^{1}$ State Key Laboratory for Diagnosis and Treatment of Infectious Diseases, The First Affiliated Hospital, Zhejiang University \\ School of Medicine, Hangzhou 310003, China \\ ${ }^{2}$ Collaborative Innovation Center for Diagnosis and Treatment of Infectious Diseases, The First Affiliated Hospital, Zhejiang \\ University School of Medicine, Hangzhou 310003, China \\ ${ }^{3}$ Department of Ultrasound Medicine, The First Affiliated Hospital, Zhejiang University School of Medicine, Hangzhou 310003, \\ China \\ ${ }^{4}$ Department of Hepatobiliary and Pancreatic Surgery, The First Affiliated Hospital, Zhejiang University School of Medicine, \\ Hangzhou 310003, China \\ Correspondence to: Weilin Wang, email: wam@zju.edu.cn \\ Tian'an Jiang, email: tiananjiang@126.com
}

Keywords: irreversible electroporation, tumor, alkaline phosphatase, aspartate aminotransferase, bilirubin

Received: August 10, $2016 \quad$ Accepted: October 28, 2016

Published: December 20, 2016

\section{ABSTRACT}

Background: Irreversible electroporation (IRE) ablation is a new technique that is used to eliminate malignant tumors through nonthermal approaches.

Objective: The purpose of this review was to evaluate the efficiency of IRE for hepatic malignant tumors.

Methods: A systematic search was performed from PubMed, Embase, Web of science, Scopus and other potential literatures from references in relevant articles July 26th, 2016. Overall estimates of pooled standard mean difference (SMD) with $95 \%$ confidence interval ( $\mathrm{CI}$ ) were calculated for the changes of the pre- and postIRE longest diameter, alkaline phosphatase (ALP), aspartate aminotransferase (AST) and serum total bilirubin levels. Sensitivity analysis and publication bias and were performed after the pooled analysis, and the quality of the included literatures was appraised using Newcastle-Ottawa Scale (NOS).

Results: We finally included 300 patients (mean age: 51 to 66.6 years; male: 182; female: 118) from 9 studies of hepatic malignant tumors. The meta-analysis showed that comparing with the initial values, the longest diameter of the tumors was significantly decreased at the last follow-up months after IRE. Furthermore, the ALP, AST and total bilirubin levels were increased at 1 day after IRE while returned to baseline at the last follow-up month. No risk of publication bias was found, and all literatures were assessed good quality according to NOS.

Conclusions: The pooled data indicated that IRE could be a minimal invasive and effective approach for patients who had preoperative poor liver function or those whose masses were in refractory locations where surgical resection was unsuitable.

\section{INTRODUCTION}

Cancer became a main threat to public health worldwide, and incidence rates have risen in most countries since 1990. Liver cancer ranked 6th and 3rd of the list for cancer incidence and cancer death in 2013, respectively. It was ranked 11 th and 7 th respectively for incidence and mortality in developed countries while 5 th and 2 nd in developing countries. In 2013, the disease resulted in 20.9 million disability adjusted life years (DALYs), with $14 \%$ in developed countries and $86 \%$ in developing countries. Liver cancer was usually diagnosed cancer and main cause of cancer death in 2013 for men in the areas such as Africa, South Asia 
and Mongolia. Similarly, this also happened for women in 2013 in Mongolia. It was reported approximately 792000 new cases of liver cancers and 818000 deaths in 2013 in the world [1]. Long-term alcohol consumption, hepatitis $\mathrm{B}$ virus (HBV) and $\mathrm{C}(\mathrm{HCV})$ are all the risk factors linked with hepatocarcinogenesis $[2,3]$. Therapy of hepatocellular carcinoma (HCC) could be curative, palliative, and symptomatic, which included surgery, transplantation, and local tumour ablation [4, 5].

Traditionally, thermal ablation techniques like radiofrequency ablation (RFA) and microwave ablation (MWA) kill target lesions by gathering thermal energy. Major limitations included low power, shaft heating, large diameter probes, and not being able to effectively treat tumors adjacent to a major blood vessel due to the "heat sink" effect and relapse easily [6-8]. It was reported a high recurrence rate from $4.6 \%$ to $48 \%$ after the thermal ablations for patients with hepatic cancer or hepatic metastases [9-11]. Unlike these existing thermal ablation techniques, irreversible electroporation (IRE) is a new nonthermal ablative technique, which triggers cell death by altering the permeability of the cellular membrane based on the pulsed direct current, and destroying the lipid bilayer integrity to enable molecules through the cell membrane [12-15]. IRE can induce tissue necrosis within micro- to millisecond ranges while conventional ablation techniques need almost from 30 minutes to hours. It also generated a clear boundary between the ablated and unablated area in vivo [16]. In the basis of these reasons, IRE could be an effective treatment option for target tumors in challenging locations of porta hepatis, gallbladder, bile ducts, pancreatic duct and ureter [17-22].

However, in recent years, numerous emerging reports, which focused on the change of the longest diameter and laboratory indexes of patients with liver cancer pre- and post-IRE [13, 15, 23-29], are still inconclusive how the variation of these parameters are. Therefore, we performed a systematic review and metaanalysis to enable a more precise evaluation of the outcomes that correlated a response to IRE.

\section{RESULTS}

\section{Study characteristics}

We finally identified from 9 studies of hepatic malignant tumors representing a total of 300 patients (male: 182; female: 118). Two thousand one hundred and thirty-eight studies were ineligible for inclusion according to predefined search strategies until July 26th, 2016 (Figure 1). Table 1 summarized the characteristics of the 7 retrospective and 3 prospective cohort studies

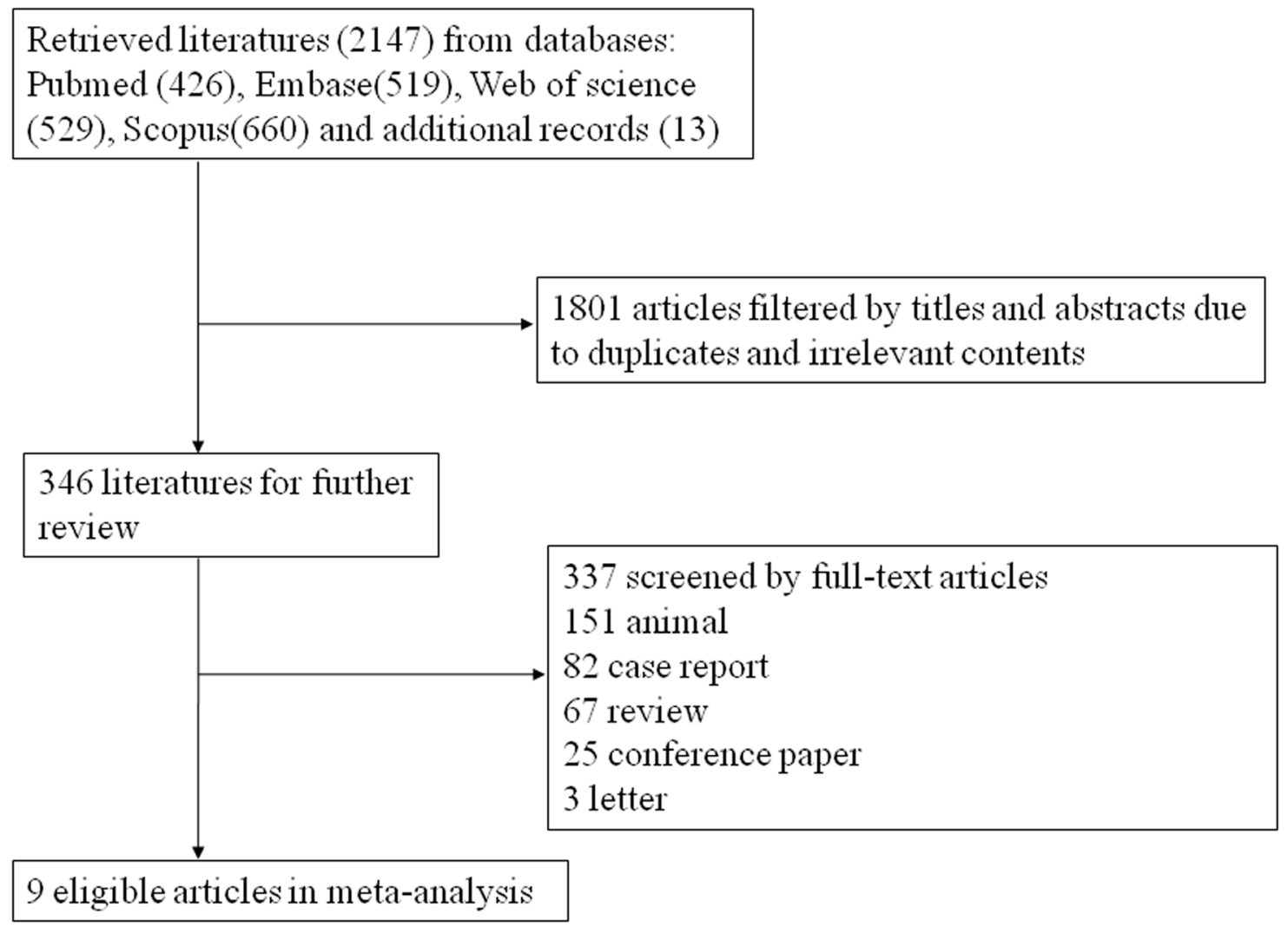

Figure 1: Flow diagram of the study selection process. 
Table 1: Summary of the included studies

\begin{tabular}{|c|c|c|c|c|c|c|c|c|c|c|c|c|c|c|}
\hline Author & Year & $\begin{array}{l}\text { Study } \\
\text { period }\end{array}$ & Design style & Country & $\begin{array}{l}\text { Population } \\
\text { characteristics }\end{array}$ & $\begin{array}{l}\text { Treatment } \\
\text { methods }\end{array}$ & $\begin{array}{c}\text { Patients } \\
\text { (No. of } \\
\text { benign } \\
\text { thyroid } \\
\text { nodules) }\end{array}$ & $\begin{array}{c}\text { Male } \\
\text { /female }\end{array}$ & $\begin{array}{c}\text { Age } \\
\text { (years) }\end{array}$ & $\begin{array}{c}\text { Follow- } \\
\text { up } \\
\text { interval } \\
\text { (months) }\end{array}$ & Complication & $\begin{array}{l}\text { Imaging } \\
\text { methods }\end{array}$ & Prognosis & $\begin{array}{l}\text { NOS } \\
\text { score }\end{array}$ \\
\hline $\begin{array}{l}\text { Dollinger } \\
\mathrm{M} \text { et al. }\end{array}$ & 2016 & NA & $\begin{array}{l}\text { Retrospective } \\
\text { cohort }\end{array}$ & Germany & $\begin{array}{l}7 \text { HCC; } 2 \\
\text { cholangiocellular } \\
\text { carcinoma; } 10 \text { metastatic } \\
\text { colorectal tumor, } \\
2 \text { metastatic breast } \\
\text { carcinoma, } 3 \text { others }\end{array}$ & $\begin{array}{l}\text { CT-guided } \\
\text { percutaneous } \\
\text { IRE }\end{array}$ & $26(53)$ & $17 / 9$ & $\begin{array}{c}59.3 \pm \\
11.2(37- \\
77)\end{array}$ & $7.2 \pm 5.3$ & NA & MR & $\begin{array}{l}\text { Local tumor } \\
\text { recurrence: } \\
18.2 \%\end{array}$ & 8 \\
\hline $\begin{array}{l}\text { Padia SA } \\
\text { et al. }\end{array}$ & 2016 & $\begin{array}{l}2011.4- \\
2013.12\end{array}$ & $\begin{array}{l}\text { Retrospective } \\
\text { cohort }\end{array}$ & USA & $20 \mathrm{HCC}$ & $\begin{array}{l}\text { US/CT-guided } \\
\text { percutaneous } \\
\text { IRE }\end{array}$ & $20(20)$ & $14 / 6$ & $62(50-76)$ & 12 & NA & MR & $\begin{array}{l}\text { Primary } \\
\text { efficacy } \\
\text { rate: } 90 \%\end{array}$ & 7 \\
\hline $\begin{array}{l}\text { Barabasch } \\
\text { A et al. }\end{array}$ & 2016 & $\begin{array}{l}2012- \\
2015\end{array}$ & $\begin{array}{l}\text { Prospective } \\
\text { cohort }\end{array}$ & Germany & $\begin{array}{l}15 \text { colorectal cancer; } \\
4 \text { breast cancer; } 2 \\
\text { pancreatic cancer; } 2 \\
\text { esophageal carcinoma; } \\
1 \text { melanoma; } 1 \\
\text { mesothelioma; } 1 \text { RCC; } \\
1 \text { GIST }\end{array}$ & $\begin{array}{l}\text { CT-guided } \\
\text { percutaneous } \\
\text { IRE }\end{array}$ & $27(37)$ & $13 / 14$ & $\begin{array}{c}62 \pm 11 \\
(46-68)\end{array}$ & $23 \pm 11$ & NA & MR & CR: $57 \%$ & 7 \\
\hline $\begin{array}{l}\text { Sugimoto } \\
\mathrm{K} \text { et al. }\end{array}$ & 2015 & $\begin{array}{l}2014.1- \\
2014.6\end{array}$ & $\begin{array}{l}\text { Prospective } \\
\text { cohort }\end{array}$ & Japan & $5 \mathrm{HCC}$ & $\begin{array}{l}\text { US-guided } \\
\text { percutaneous } \\
\text { IRE }\end{array}$ & $5(6)$ & $3 / 2$ & $\begin{array}{c}66.6 \pm \\
5.8\end{array}$ & 8 & No & $\mathrm{CT} / \mathrm{MR} / \mathrm{US}$ & $\begin{array}{l}2 \text { new } \\
\text { lesions }\end{array}$ & 6 \\
\hline $\begin{array}{l}\text { Niessen C } \\
\text { et al. }\end{array}$ & 2015 & $\begin{array}{c}2011.12- \\
2013.3\end{array}$ & $\begin{array}{l}\text { Prospective } \\
\text { cohort }\end{array}$ & Germany & $\begin{array}{l}22 \text { HCC; } \\
6 \text { cholangiocellular } \\
\text { carcinoma; } 16 \text { colorectal } \\
\text { metastasis; } 4 \text { other } \\
\text { metastasis }\end{array}$ & $\begin{array}{l}\text { US/CT-guided } \\
\text { percutaneous } \\
\text { IRE }\end{array}$ & $25(48)$ & $21 / 4$ & $\begin{array}{c}59.4 \pm \\
11.2\end{array}$ & 6 & NA & MR & $\begin{array}{l}\text { Local } \\
\text { recurrence } \\
\text { rate: } 29.2 \%\end{array}$ & 7 \\
\hline $\begin{array}{l}\text { Froud T } \\
\text { et al. }\end{array}$ & 2015 & $\begin{array}{l}2010.1- \\
2014.10\end{array}$ & $\begin{array}{l}\text { Retrospective } \\
\text { cohort }\end{array}$ & USA & $\begin{array}{l}62 \text { metastatic disease; } \\
53 \text { hepatocellular } \\
\text { carcinoma; } 8 \\
\text { cholangiocarcinoma; } \\
1 \text { unknown }\end{array}$ & CT-guided IRE & 124 & $71 / 53$ & $\begin{array}{c}59.8 \pm \\
11.4\end{array}$ & 2 & NA & PET & NA & 9 \\
\hline $\begin{array}{l}\text { Dollinger } \\
\mathrm{M} \text { et al. }\end{array}$ & 2014 & NA & $\begin{array}{l}\text { Retrospective } \\
\text { cohort }\end{array}$ & Germany & $\begin{array}{l}14 \text { HCC; } 11 \\
\text { colorectal tumor; } \\
5 \text { cholangiocellular } \\
\text { carcinoma; } \\
1 \text { seminomatous } \\
\text { testicular tumor; } \\
1 \text { esophageal carcinoma; } \\
1 \text { neuroendocrine tumor; } \\
1 \text { other }\end{array}$ & $\begin{array}{l}\text { CT-guided } \\
\text { percutaneous } \\
\text { IRE }\end{array}$ & $34(52)$ & $28 / 6$ & $\begin{array}{c}64 \\
(22-80)\end{array}$ & $\begin{array}{c}4.7(0.3- \\
17)\end{array}$ & $\begin{array}{l}4 \text { hepatic } \\
\text { abscesses }\end{array}$ & $\mathrm{CT}$ & $\begin{array}{l}\text { Reduction } \\
\text { in volume } \\
\text { to } 29 \% \text { of } \\
\text { initial value }\end{array}$ & 7 \\
\hline $\begin{array}{l}\text { Silk MT } \\
\text { et al. }\end{array}$ & 2014 & $\begin{array}{l}2011.1- \\
2012.9\end{array}$ & $\begin{array}{l}\text { Retrospective } \\
\text { cohort }\end{array}$ & USA & $\begin{array}{l}16 \text { metastatic } \\
\text { colorectal carcinoma; } \\
5 \text { metastatic pancreatic } \\
\text { carcinoma; } 1 \text { metastatic } \\
\text { hemangiopericytoma }\end{array}$ & $\begin{array}{l}\mathrm{CT} \text { or } \mathrm{PET} / \mathrm{CT} \\
\text { percutaneous } \\
\text { IRE }\end{array}$ & $11(22)$ & $4 / 7$ & $\begin{array}{c}60 \\
(45-81)\end{array}$ & $9 \pm 6$ & $\begin{array}{l}1 \text { bile duct } \\
\text { dilatation }\end{array}$ & $\mathrm{CT}$ & $\begin{array}{l}\text { Local tumor } \\
\text { recurrence: } \\
54.5 \%\end{array}$ & 6 \\
\hline $\begin{array}{l}\text { Kingham } \\
\text { TP et al. }\end{array}$ & 2012 & $\begin{array}{l}\text { 2011.1.1- } \\
\text { 2011.11.2 }\end{array}$ & $\begin{array}{l}\text { Retrospective } \\
\text { cohort }\end{array}$ & USA & $\begin{array}{l}21 \text { metastatic colorectal } \\
\text { cancer; } 2 \text { HCC; } \\
2 \text { metastatic pancreatic } \\
\text { neuroendocrine; } \\
1 \text { metastatic } \\
\text { ampullary carcinoma; } \\
1 \text { hemangiopericytoma; } \\
1 \text { leiomyosarcoma } \\
\text { metastasis tumor }\end{array}$ & $\begin{array}{l}\text { US/CT- } \\
\text { guided open/ } \\
\text { percutaneous } \\
\text { IRE }\end{array}$ & $28(65)$ & $11 / 17$ & $51(32-81)$ & $6(1-9)$ & $\begin{array}{l}1 \text { intraoperative } \\
\text { arrhythmia; } 1 \\
\text { postoperative } \\
\text { portal vein } \\
\text { thrombosis }\end{array}$ & $\mathrm{CT} / \mathrm{MR}$ & $\begin{array}{l}\text { Persistent } \\
\text { disease } \\
\text { rate: } 1.9 \% \text {; } \\
\text { local } \\
\text { recurrence } \\
\text { rate: } 5.7 \%\end{array}$ & 7 \\
\hline
\end{tabular}

NA:not available;

CR:complete response;

RCC: renal cell carcinoma;

GIST: gastrointestinal stromal tumor;

HCC: hepatocellular carcinoma;

US:ultrasound;

CT: Computed Tomography;

MR: Magnetic Resonance;

NOS: Newcastle-Ottawa Scale.

with the mean follow-up between 2 and 23 months. The mean age of included participants ranged from 51 to 66.6 years. The treated tumors in these studies of recent decades mainly included primary and metastatic hepatic disease, in which US/CT-guided percutaneous IRE became the main treatment methods. Furthermore, it showed IRE had a few major complications including 4 hepatic abscesses, 1 bile duct dilatation, 1 arrhythmia, 1 portal vein thrombosis in Table 1 and these patients in this study had a better prognosis. Most of these observational studies were of good quality ranging from 6 to 9 scores using the Newcastle-Ottawa scale. Risk of bias was described in Supplementary Table 1. 


\section{Meta-analysis results}

\section{Heterogeneity test result}

Results of this meta-analysis showed that comparing with the initial values, the longest diameter of the tumors was significantly decreased at the last follow-up month after IRE (1 month, SMD 95\%CI: 0.447(0.189-0.704)). Furthermore, the ALP, AST and total bilirubin levels were increased at 1 day after IRE while unchanged at the last follow-up month (Table 2, Supplementary Figure 1-4) (ALP: 1 day, SMD 95\%CI: $-0.5(-0.88--0.12)$; the last follow-up month, SMD 95\%CI: 0.228(-0.223-0.679); AST: 1 day, SMD 95\%CI: -2.82(-4.296-1.343); the last follow-up month, SMD 95\%CI: -0.028(-0.511-0.454); total bilirubin: 1 day, SMD 95\%CI: -0.902(-1.254--0.551); the last follow-up month, SMD 95\%CI: $-0.131(-0.551-$ $0.288)$ ).

\section{Sensitivity analyses and publication bias}

Assessment of the subgroup analysis were generally in accordance with the sensitivity analysis. No evidence of publication bias was found by means of funnel plot asymmetry and Egger's linear regression test (Table 2).

\section{DISCUSSION}

Liver cancer contributed a lot to the total burden of cancer, which ranked the third in most common causes of cancer death worldwide. The incidence was still highest in the developing world while rising in the developed world [30]. The pooled data of meta-analysis showed the increased ALP, AST and total bilirubin levels at 1 day after IRE while decreased longest diameter, unchanged ALP, AST and total bilirubin levels at the last followup months. Although there were a small number of complications such as arrhythmia, portal vein thrombosis, bile duct dilatation and hepatic abscesses, it suggested that IRE may be a potential candidate of primary or metastatic liver malignancies.

Our study showed that the longest diameter was decreased a few months later. In previous study, it showed after about 4.7 months follow-up, CT scans found a decrease in volume to $29 \%$ and in diameter to $61 \%$ comparing with the initial values [27]. A retrospective study by MR imaging appearances of treated tumors revealed there was a decrease of $28.9 \%$ in size of the ablation zone at day 90 versus day 1 after IRE [13], which was similar to another systematic longitudinal study [24]. However, a research of $24 \mathrm{HCC}$ lesions in 20 patients showed no significant difference in the largest diameter during the 18-month period [31]. Nevertheless, the curative effect of IRE was still attractive. Recent studies have detected the increased plasma levels of IL-6 and IL-10 induced by different ablation modalities [32]. Continuous opening of microvessels in the coagulated zone from IRE enlarged the area and accumulation of infiltrative cells, leading to more robust systemic reactions including tumorigenic and immunogenic effects compared to RFA [33]. Furthermore, it was reported that cell death of IRE has enhanced BAX (BCL-2) staining comparing with non-ablated area, which suggested the impact of electroporation on the apoptosis rather than RFA on the thermal coagulative necrosis [34]. The cellular tissue could be repaired, which was observed in the pathologic analysis showing hepatocyte proliferation about 24 hours after ablation. It may be that apoptotic cells were quickly eliminated by phagocytosis and replaced with innate cellular regeneration [35]. These may lead to the decreased masses and indicated that IRE is a promising approach to deal with hepatic malignant tumors.

Besides the longest diameter in our study, rapid elevations after IRE were seen within 24 hours in the liver transaminases of ALP and AST, which were signals of hepatocellular injury or necrosis. It was reported that AST locating in hepatocytes leaked out into the bloodstream due to the hepatocellular damage [36]. In this study, the transaminases returned to baseline following one or two months. Serum bilirubin also rose to peak level on day 1 and normalized two months later. The peak values of elevation were consistent with those of other ablation modalities. Previous study showed that the change in AST levels after cryotherapy of liver tumors was associated with the thrombocytopenia level and could be a potential early signal of severe thrombocytopenia [37] while ALP levels were the most sensitive biochemical marker of cholestasis [38]. Thus physicians could not be frightened by the early rapid elevation in AST, ALT and total bilirubin levels in the event of hepatocellular damage and cell death after IRE, of which postoperative regular follow-up should be necessary.

Several limitations were arisen from this study, perhaps the most important of which was the limited sample that has different hepatic tumor types with various histological characteristics might have impacts on the treatment response. Secondly, we conducted this study based on the different imaging methods such as CT, MRI and ultrasonography, which may cause the measuring error. Thirdly, some drugs of anesthetic agents like halothane; antibiotics like amoxicillin, ciprofloxacin; and analgesics like acetaminophen could have toxic effects on the liver by directly influencing hepatocytes or regulating an immune response [39].

In spite of these limitations, the meta-analysis provided evidence that IRE might be effective for patients with challenging hepatic malignant tumors. All published literatures about this subject were seriously searched and cross-checked by two individual investigators through relevant protocols. We also carefully extracted and combined data in each study to provide a robust evaluation of post-IRE outcomes. 
Table 2: Subgroup analysis of the outcomes of IRE for hepatic malignant tumors

\begin{tabular}{|c|c|c|c|c|c|c|c|c|c|c|}
\hline \multirow[t]{2}{*}{ Subgroup } & \multirow{2}{*}{$\begin{array}{l}\text { Number of } \\
\text { studies }\end{array}$} & \multirow[t]{2}{*}{ SMD $(95 \% C I)$} & \multirow{2}{*}{$\begin{array}{c}\mathrm{Z} \\
\text { score }\end{array}$} & \multirow{2}{*}{$p$} & \multicolumn{2}{|c|}{$\begin{array}{c}\text { Heterogeneity } \\
\text { test }\end{array}$} & \multirow[b]{2}{*}{$I^{2}(\%)$} & \multirow[b]{2}{*}{$p$} & \multicolumn{2}{|c|}{$\begin{array}{c}\text { Publication } \\
\text { bias }\end{array}$} \\
\hline & & & & & $\mathbf{Q}$ & $\tau^{2}$ & & & $t$ & $p$ \\
\hline $\begin{array}{l}\text { Largest } \\
\text { diameter }\end{array}$ & 5 & $0.447(0.189-0.704)$ & 3.4 & 0.001 & 7.86 & NA & 49.1 & 0.097 & -0.9 & 0.434 \\
\hline \multicolumn{11}{|l|}{ ALP } \\
\hline 1 day & 3 & $-0.5(-0.88--0.12)$ & 2.58 & 0.01 & 4.17 & NA & 52.1 & 0.124 & -0.51 & 0.7 \\
\hline Last month & 2 & $0.228(-0.223-0.679)$ & 0.99 & 0.322 & 3.79 & NA & 73.6 & 0.051 & NA & NA \\
\hline \multicolumn{11}{|l|}{$\mathrm{AST}$} \\
\hline 1 day & 3 & $-2.82(-4.296-1.343)$ & 3.74 & $<0.001$ & 17.41 & 1.3403 & 88.5 & $<0.001$ & -1.9 & 0.309 \\
\hline Last month & 2 & $\begin{array}{c}-0.028(-0.511- \\
0.454)\end{array}$ & 0.12 & 0.908 & 0.08 & NA & 0 & 0.784 & NA & NA \\
\hline \multicolumn{11}{|l|}{ Total bilirubin } \\
\hline 1 day & 4 & $\begin{array}{c}-0.902(-1.254-- \\
0.551)\end{array}$ & 5.03 & $<0.001$ & 0.1 & NA & 0 & 0.991 & -1.56 & 0.259 \\
\hline Last month & 3 & $\begin{array}{c}-0.131(-0.551- \\
0.288)\end{array}$ & 0.61 & 0.54 & 0.76 & NA & 0 & 0.685 & -0.94 & 0.521 \\
\hline
\end{tabular}

ALP: alkaline phosphatase; AST: aspartate aminotransferase; SMD: standardized mean difference; CI: confidence interval. SMD test was estimated by $\mathrm{Z}$ score. In SMD test, $p<0.05$ indicates the result significant.

Heterogeneity was appraised by Q, $\tau^{2}$ and $I^{2}$ statistics. Q value indicates random error; Tau2 $\left(\tau^{2}\right)$ value means the variations between studies; $I^{2}$ value represents the percentage of inter-study difference in the overall heterogeneity.

\section{MATERIALS AND METHODS}

\section{Search strategy}

This meta-analysis was seriously performed according to the PRISMA statement [40]. We searched all studies based on PubMed, Embase, Web of science and Scopus from database inception to July 26th, 2016, where the keywords "irreversible electroporation", "IRE", "nanoknife", "liver", "hepartic" were used. Detailed search strategies for each database were available in Supplementary File. We also earnestly checked references in the included studies of other potential articles.

\section{Inclusion criteria}

We selected studies according to the criterias as follows: 1) original article; 2) prospective or retrospective studies, including cohorts and trials; 3 ) primary or metastatic liver malignancies treated with percutaneous IRE; 4) it provided sufficient data to calculate these estimates including the longest diameter, alkaline phosphatase (ALP), aspartate aminotransferase (AST) and serum total bilirubin.

\section{Exclusion criteria}

These studies would be ineligible with the criterias below: 1) case reports, case series, and animal studies; 2) benign hepatic lesions; 3) If studies had multiple reports, the latest or most complete article was retained; 4) patients with pacemakers, a history of cardiac arrhythmias, metastases in several other organs, and extremely large lesions [6].

\section{Data extraction and literature quality assessment}

All the retrieve data were imported into reference management software (Endnote X7, free trial version, Zhejiang University School of Medicine, Hangzhou, China) after the electronical or manual removal of duplicate citations. The rest articles were screened and checked by two individual investigators according to the pre-defined criteria. The information extracted from each paper included author, publication year, study period, design style, country, population characteristics, treatment methods, number of the tumor, male or female number, age, follow-up interval, complication, imaging methods, prognosis and NOS score. We also attempted to email to authors for additional information if necessary. 
Disagreements were discussed to be determined with a third reviewer. In addition, two investigators independently cross-checked the risk of bias using the Newcastle-Ottawa Scale for observational studies.

\section{Statistical analysis}

Comparing with the initial values, the meta-analysis checked the changes of the longest diameter, alkaline phosphatase (ALP), aspartate aminotransferase (AST) and serum total bilirubin at 1 day and the last follow-up months after IRE. For each study, we estimated standard mean difference (SMD) and its 95\% CIs for each outcome. We estimated the heterogeneity across studies using the Q statistic [41], $\tau^{2}$ and $I^{2}=100 \% \times(\mathrm{Q}-\mathrm{df}) / \mathrm{Q}$ [42]. If a two-sided $p$ value was less than 0.05 considered as statistically significant, then a random-effect model was used. Otherwise, a fixed-effect model would be applied. In addition, sensitivity analysis was used to appraise the impact of the remaining studies without the larger one's effect. We calculated the effect of publication bias by the Egger regression asymmetry test and funnel plots [43]. In this study, Stata 12.0 software (Stata Corp, College Station, Texas) was conducted for all statistical analyses.

\section{CONCLUSION}

In conclusion, our data suggested that IRE, based on its advantage of minimal invasive approach, could be a candidate for patients who had preoperative poor liver reserve capacity or those whose masses were in refractory locations where surgical resection was unsuitable and devastative. And furthermore, more prospective largescale studies with the long-term follow-up should be performed to confirm this in the future.

\section{Abbreviations}

IRE $=$ Irreversible electroporation; $\mathrm{SMD}=$ standard mean difference; $\mathrm{CI}=$ confidence interval; $\mathrm{ALP}=$ alkaline phosphatase; $\quad$ AST $=$ aspartate aminotransferase; NOS=Newcastle-Ottawa Scale; DALYs=disability adjusted life years; $\mathrm{HBV}=$ hepatitis $\mathrm{B}$ virus; $\mathrm{HCV}=$ hepatitis $\mathrm{C}$ virus; $\mathrm{HCC}=$ hepatocellular carcinoma; $\mathrm{RFA}=$ radiofrequency ablation; $\mathrm{MWA}=$ microwave ablation; PRISMA=Preferred Reporting Items for Systematic Reviews and Meta-Analyses; IL$6=$ interleukin-6; BCL-2=B-cell lymphoma-2.

\section{CONFLICTS OF INTEREST}

The funders had a role in preparation of the manuscript and publication.

\section{FINANCIAL SUPPORT}

This work was supported by grants from the National Natural Science Foundation of China (No.
81572307), the Science and Technology Project of Zhejiang Province (2014C13G2010059).

\section{Author contributions}

1. Study concept and design: Guo Tian, Weilin Wang.

2. Acquisition of data: Guo Tian, Tian'an Jiang, Qiyu Zhao, Weilin Wang.

3. Analysis and interpretation of data: Guo Tian, Fen Chen, Tian'an Jiang, Qiyu Zhao.

4. Drafting of the manuscript: Guo Tian, Tian'an Jiang.

5. Critical revision of the manuscript for important intellectual content: Guo Tian, Weilin Wang.

6. Statistical analysis: Tian'an Jiang, Qiyu Zhao.

7. Obtained funding: Weilin Wang.

8. Technical, or material support: Guo Tian, Fen

Chen, Tian'an Jiang, Qiyu Zhao.

9. Study supervision: Weilin Wang, Tian'an Jiang.

\section{REFERENCES}

1. Global Burden of Disease Cancer Collaboration. The Global Burden of Cancer 2013. JAMA Oncol. 2015; 1:505527. doi: 10.1001/jamaoncol.2015.0735.

2. Thein HH, Walter SR, Gidding HF, Amin J, Law MG, George J, Dore GJ. Trends in incidence of hepatocellular carcinoma after diagnosis of hepatitis B or $\mathrm{C}$ infection: a population-based cohort study, 1992-2007. Journal of viral hepatitis. 2011; 18:e232-241.

3. Tanaka K, Hirohata T, Takeshita S, Hirohata I, Koga S, Sugimachi K, Kanematsu T, Ohryohji F, Ishibashi H. Hepatitis B virus, cigarette smoking and alcohol consumption in the development of hepatocellular carcinoma: a case-control study in Fukuoka, Japan. International journal of cancer. 1992; 51:509-514.

4. Bhardwaj N, Perera MT, Silva MA. Current Treatment Approaches to HCC with a Special Consideration to Transplantation. Journal of transplantation. 2016; 2016:7926264.

5. Kouri BE, Abrams RA, Al-Refaie WB, Azad N, Farrell J, Gaba RC, Gervais DA, Gipson MG, Kolbeck KJ, Marshalleck FE, Pinchot JW, Small W, Jr., Ray CE, Jr., et al. ACR Appropriateness Criteria Radiologic Management of Hepatic Malignancy. Journal of the American College of Radiology. 2016; 13:265-273.

6. Narayanan G. Irreversible electroporation for treatment of liver cancer. Gastroenterology \& hepatology. 2011; 7:313-316.

7. Lubner MG, Brace CL, Ziemlewicz TJ, Hinshaw JL, Lee FT, Jr. Microwave ablation of hepatic malignancy. Seminars in interventional radiology. 2013; 30:56-66.

8. Mulier S, Ni Y, Jamart J, Ruers T, Marchal G, Michel L. Local recurrence after hepatic radiofrequency coagulation: 
multivariate meta-analysis and review of contributing factors. Annals of surgery. 2005; 242:158-171.

9. Raut CP, Izzo F, Marra P, Ellis LM, Vauthey JN, Cremona F, Vallone P, Mastro A, Fornage BD, Curley SA. Significant long-term survival after radiofrequency ablation of unresectable hepatocellular carcinoma in patients with cirrhosis. Annals of surgical oncology. 2005; 12:616-628.

10. Kingham TP, Tanoue M, Eaton A, Rocha FG, Do R, Allen P, De Matteo RP, D'Angelica M, Fong Y, Jarnagin WR. Patterns of recurrence after ablation of colorectal cancer liver metastases. Annals of surgical oncology. 2012; 19:834-841.

11. Solbiati L, Ierace $\mathrm{T}$, Tonolini M, Osti V, Cova L. Radiofrequency thermal ablation of hepatic metastases. European journal of ultrasound. 2001; 13:149-158.

12. Yarmush ML, Golberg A, Sersa G, Kotnik T, Miklavcic D. Electroporation-based technologies for medicine: principles, applications, and challenges. Annual review of biomedical engineering. 2014; 16:295-320.

13. Padia SA, Johnson GE, Yeung RS, Park JO, Hippe DS, Kogut MJ. Irreversible Electroporation in Patients with Hepatocellular Carcinoma: Immediate versus Delayed Findings at MR Imaging. Radiology. 2016; 278:285-294.

14. Guo Y, Zhang Y, Klein R, Nijm GM, Sahakian AV, Omary RA, Yang GY, Larson AC. Irreversible electroporation therapy in the liver: longitudinal efficacy studies in a rat model of hepatocellular carcinoma. Cancer research. 2010; 70:1555-1563.

15. Froud T, Venkat SR, Barbery KJ, Gunjan A, Narayanan G. Liver Function Tests Following Irreversible Electroporation of Liver Tumors: Experience in 174 Procedures. Techniques in vascular and interventional radiology. 2015; 18:140-146.

16. Edd JF, Horowitz L, Davalos RV, Mir LM, Rubinsky B. In vivo results of a new focal tissue ablation technique: irreversible electroporation. IEEE Transactions on Biomedical Engineering. 2006; 53:1409-1415.

17. Herwald SE, Chen JH, Arellano RS. Irreversible Electroporation for Treatment of Hepatocellular Carcinoma Adjacent to the Gallbladder. Journal of vascular and interventional radiology. 2016; 27:1093-1094.

18. Choi JW, Lu DS, Osuagwu F, Raman S, Lassman C. Assessment of chronological effects of irreversible electroporation on hilar bile ducts in a porcine model. Cardiovascular and interventional radiology. 2014; 37:224-230.

19. Savic LJ, Chapiro J, Hamm B, Gebauer B, Collettini F. Irreversible Electroporation in Interventional Oncology: Where We Stand and Where We Go. RoFo. 2016; 188:735-745.

20. Mansson C, Brahmstaedt R, Nilsson A, Nygren P, Karlson BM. Percutaneous irreversible electroporation for treatment of locally advanced pancreatic cancer following chemotherapy or radiochemotherapy. European journal of surgical oncology. 2016; 42:1401-1406.

21. Srimathveeravalli G, Silk M, Wimmer T, Monette S, Kimm S, Maybody M, Solomon SB, Coleman J, Durack JC. Feasibility of catheter-directed intraluminal irreversible electroporation of porcine ureter and acute outcomes in response to increasing energy delivery. Journal of vascular and interventional radiology. 2015; 26:1059-1066.

22. Martin RC, 2nd, Kwon D, Chalikonda S, Sellers M, Kotz E, Scoggins C, McMasters KM, Watkins K. Treatment of 200 locally advanced (stage III) pancreatic adenocarcinoma patients with irreversible electroporation: safety and efficacy. Annals of surgery. 2015; 262:486-494; discussion 492-484.

23. Dollinger M, Zeman F, Niessen C, Lang SA, Beyer LP, Muller M, Stroszczynski C, Wiggermann P. Bile Duct Injury after Irreversible Electroporation of Hepatic Malignancies: Evaluation of MR Imaging Findings and Laboratory Values. Journal of vascular and interventional radiology. 2016; 27:96-103.

24. Barabasch A, Distelmaier M, Heil P, Kramer NA, Kuhl CK, Bruners P. Magnetic Resonance Imaging Findings After Percutaneous Irreversible Electroporation of Liver Metastases: A Systematic Longitudinal Study. Investigative radiology. 2016; 52:23-29.

25. Sugimoto K, Moriyasu F, Kobayashi Y, Saito K, Takeuchi H, Ogawa S, Ando M, Sano T, Mori T, Furuichi Y, Nakamura I. Irreversible electroporation for nonthermal tumor ablation in patients with hepatocellular carcinoma: initial clinical experience in Japan. Japanese journal of radiology. 2015; 33:424-432.

26. Niessen C, Igl J, Pregler B, Beyer L, Noeva E, Dollinger M, Schreyer AG, Jung EM, Stroszczynski C, Wiggermann P. Factors associated with short-term local recurrence of liver cancer after percutaneous ablation using irreversible electroporation: a prospective single-center study. Journal of vascular and interventional radiology. 2015; 26:694-702.

27. Dollinger M, Jung EM, Beyer L, Niessen C, Scheer F, Muller-Wille R, Stroszczynski C, Wiggermann P. Irreversible electroporation ablation of malignant hepatic tumors: subacute and follow-up CT appearance of ablation zones. Journal of vascular and interventional radiology. 2014; 25:1589-1594.

28. Silk MT, Wimmer T, Lee KS, Srimathveeravalli G, Brown KT, Kingham PT, Fong Y, Durack JC, Sofocleous CT, Solomon SB. Percutaneous ablation of peribiliary tumors with irreversible electroporation. Journal of vascular and interventional radiology. 2014; 25:112-118.

29. Kingham TP, Karkar AM, D'Angelica MI, Allen PJ, Dematteo RP, Getrajdman GI, Sofocleous CT, Solomon SB, Jarnagin WR, Fong Y. Ablation of perivascular hepatic malignant tumors with irreversible electroporation. Journal of the American College of Surgeons. 2012; 215:379-387. 
30. Wang X, Zhang A, Sun H. Power of metabolomics in diagnosis and biomarker discovery of hepatocellular carcinoma. Hepatology. 2013; 57:2072-2077.

31. Granata V, de Lutio di Castelguidone E, Fusco R, Catalano O, Piccirillo M, Palaia R, Izzo F, Gallipoli AD, Petrillo A. Irreversible electroporation of hepatocellular carcinoma: preliminary report on the diagnostic accuracy of magnetic resonance, computer tomography, and contrast-enhanced ultrasound in evaluation of the ablated area. La Radiologia medica. 2016; 121:122-131.

32. Erinjeri JP, Thomas CT, Samoilia A, Fleisher M, Gonen M, Sofocleous CT, Thornton RH, Siegelbaum RH, Covey AM, Brody LA, Alago W, Jr., Maybody M, Brown KT, et al. Image-guided thermal ablation of tumors increases the plasma level of interleukin-6 and interleukin-10. Journal of vascular and interventional radiology. 2013; 24:1105-1112.

33. Bulvik BE, Rozenblum N, Gourevich S, Ahmed M, Andriyanov AV, Galun E, Goldberg SN. Irreversible Electroporation versus Radiofrequency Ablation: A Comparison of Local and Systemic Effects in a SmallAnimal Model. Radiology. 2016; 280:413-424.

34. Lee EW, Loh CT, Kee ST. Imaging guided percutaneous irreversible electroporation: ultrasound and immunohistological correlation. Technology in cancer research \& treatment. 2007; 6:287-294.

35. Rubinsky B, Onik G, Mikus P. Irreversible electroporation: a new ablation modality--clinical implications. Technology in cancer research \& treatment. 2007; 6:37-48.

36. Nakazawa T, Kokubu S, Shibuya A, Ono K, Watanabe M, Hidaka H, Tsuchihashi T, Saigenji K. Radiofrequency ablation of hepatocellular carcinoma: correlation between local tumor progression after ablation and ablative margin. AJR American journal of roentgenology. 2007; 188:480-488.

37. Nair RT, Silverman SG, Tuncali K, Obuchowski NA, vanSonnenberg E, Shankar S. Biochemical and hematologic alterations following percutaneous cryoablation of liver tumors: experience in 48 procedures. Radiology. 2008; 248:303-311.

38. Frederiks WM, Van Noorden CJ, Aronson DC, Marx F, Bosch KS, Jonges GN, Vogels IM, James J. Quantitative changes in acid phosphatase, alkaline phosphatase and 5 '-nucleotidase activity in rat liver after experimentally induced cholestasis. Liver. 1990; 10:158-166.

39. Lee WM. Drug-induced hepatotoxicity. The New England journal of medicine. 2003; 349:474-485.

40. Liberati A, Altman DG, Tetzlaff J, Mulrow C, Gotzsche PC, Ioannidis JP, Clarke M, Devereaux PJ, Kleijnen J, Moher D. The PRISMA statement for reporting systematic reviews and meta-analyses of studies that evaluate health care interventions: explanation and elaboration. PLoS medicine. 2009; 6:e1000100.

41. Cochran WG. The combination of estimates from different experiments. Biometrics. 1954; 10:101-129.

42. Higgins JP, Thompson SG. Quantifying heterogeneity in a meta-analysis. Statistics in medicine. 2002; 21:1539-1558.

43. Sterne JA, Sutton AJ, Ioannidis JP, Terrin N, Jones DR, Lau J, Carpenter J, Rucker G, Harbord RM, Schmid CH, Tetzlaff J, Deeks JJ, Peters J, et al. Recommendations for examining and interpreting funnel plot asymmetry in meta-analyses of randomised controlled trials. Bmj. 2011; 343:d4002. 